\title{
Differential expression of testin and survivin in breast cancer subtypes
}

\author{
MANUELA SARTI $^{1,2}$, SANDRA PINTON $^{1}$, COSTANZO LIMONI $^{3}$, GIUSEPPINA M. CARBONE $^{1,2}$, \\ OLIVIA PAGANI ${ }^{2}$, FRANCO CAVALLI ${ }^{2}$ and CARLO V. CATAPANO ${ }^{1,2}$ \\ ${ }^{1}$ Institute of Oncology Research (IOR), 6500 Bellinzona; ${ }^{2}$ Oncology Institute of Southern Switzerland (IOSI), \\ 6500 Bellinzona; ${ }^{3}$ Biometrics 'Alpha 5', 6826 Riva San Vitale, Switzerland
}

Received February 14, 2013; Accepted April 17, 2013

DOI: $10.3892 /$ or.2013.2502

\begin{abstract}
Testin (TES) is a putative tumour-suppressor gene downregulated in various types of cancers. Survivin is a nodal protein involved in multiple signalling pathways, tumour maintenance and inhibition of apoptosis. Previous studies indicate that TES and survivin can functionally interact and modulate cell death and proliferation in breast cancer cells. The aim of the present study was to investigate the expression and prognostic relevance of TES and survivin in breast cancer subtypes examining a large cohort of breast cancer patients. We determined the expression of TES and survivin by immunohistochemistry (IHC) in tissue samples from 242 breast cancer patients diagnosed between 1981 and 2009. The expression of these proteins was compared with clinical and pathological data. There was a significant association of nuclear survivin overexpression and TES downregulation with triple-negative tumours $[\mathrm{P}=0.009$; univariate odds ratio (OR), 3.20; $95 \%$ CI, 1.34-7.66] $(\mathrm{P}=0.018$; multivariate $\mathrm{OR}, 2.90 ; 95 \% \mathrm{CI}$, 1.20-6.97). A further significant correlation was observed between TES downregulation and the luminal B subtype $(\mathrm{P}=0.019$, univariate OR: 2.90; 95\% CI, 1.19-7.06) $(\mathrm{P}=0.032$, multivariate OR, 2.67; 95\% CI, 1.09-6.65), independent of survivin expression. Our results demonstrated a statistically significant association between TES downregulation and highly aggressive breast tumour subtypes, such as triplenegative and luminal B tumours, along with the prognostic relevance of nuclear expression of survivin. To our knowledge, this is the first demonstration of such an association.
\end{abstract}

\section{Introduction}

Breast cancer is the most common cancer among women worldwide and is a highly heterogeneous disease. Therefore, there is a pressing need for methods with which to stratify

Correspondence to: Dr Manuela Sarti, Institute of Oncology Research (IOR), Via Vela 6, 6500 Bellinzona, Switzerland

E-mail: manuela.sarti@eoc.ch

Key words: breast cancer, triple-negative breast cancer, luminal B breast cancer, testin, survivin patients into the different risk groups more accurately than the current clinicopathological classifications (1-4). A molecular-based approach to classify breast tumours was first proposed by Sørlie et al (5). In this study, breast carcinomas were clustered based on gene expression profiles determined using DNA microarrays. Breast tumours were divided into luminal A [estrogen receptor-positive $\left(\mathrm{ER}^{+}\right)$and/or progesterone receptor-positive $\left(\mathrm{PR}^{+}\right) /$human epidermal growth factor receptor 2-negative (HER2-)], luminal $\mathrm{B}\left(\mathrm{ER}^{+}\right.$and/or $\mathrm{PR}^{+} / \mathrm{HER}^{+}$), basal-like, HER2 ${ }^{+}$and normal-like breast cancer. These subtypes are associated with distinct prognosis and treatment options. Immunohistochemical-based molecular classifications have also been proposed alternatively (6-8). Immunohistochemistry (IHC) has been demonstrated to be an efficient and acceptable surrogate of gene expression analysis (6,9-11). Several lines of evidence have confirmed that the subclassification of $\mathrm{ER}^{+}$cancers and the prognostic value of gene signatures is largely driven by the expression levels of proliferation-related genes and that proliferation markers, such as Ki67, may provide equivalent prognostic information to that provided by gene signatures. In particular, according to the new St. Gallen consensus recommendations, Ki67 is one of the prognostic markers that is considered important to subclassify luminal A and luminal B, together with HER2 expression (12). The absence of ER, PR and HER2 is used to define the triple-negative subtype, which represents $\sim 15 \%$ of breast tumours and is not a homogeneous entity (13-15). Thus, new prognostic and/or predictive factors may provide additional risk stratifications to better guide treatment decisions in these different subtypes of breast cancer.

Survivin (also called baculoviral inhibitor of apoptosis repeat-containing $5, \mathrm{BIRC5}$ ) is a member of the family of inhibitor of apoptosis proteins (IAP) and is a multifunctional protein implicated in a number of cellular processes, including apoptosis, mitosis and angiogenesis (16). Survivin is present during fetal development and is rarely detectable, but is sometimes present in terminally differentiated normal adult tissues (17-19). Importantly, survivin is abundantly expressed in most types of cancers, including breast, colorectal, lung, gastric, bladder and liver cancer, melanoma and malignant lymphoma (20). The incidence of survivin expression in cancer is reported to range from 30 up to $100 \%$ (21). High survivin expression is associated with poor prognosis in most human 
Table I. Clinicopathological data of the patient cohort.

\begin{tabular}{|c|c|}
\hline Variables & Total $(n=242)(9$ \\
\hline Age (years, mean \pm SD) & $54.6 \pm 12.0$ \\
\hline \multicolumn{2}{|l|}{ Histologic subtype } \\
\hline Ductal & $219(90.5)$ \\
\hline Lobular & $23(9.5)$ \\
\hline \multicolumn{2}{|l|}{ Lymph node status } \\
\hline Negative & $134(55.4)$ \\
\hline Positive & $104(42.9)$ \\
\hline Unknown & 4 (1.7) \\
\hline \multicolumn{2}{|l|}{ Histologic grade } \\
\hline $\mathrm{I}$ & $32(13.2)$ \\
\hline II & $122(50.4)$ \\
\hline III & $87(36.0)$ \\
\hline Unknown & $1 \quad(0.4)$ \\
\hline \multicolumn{2}{|l|}{ Tumour stage } \\
\hline 0 & 7 (2.9) \\
\hline I & $92(38.0)$ \\
\hline II & $111(45.9)$ \\
\hline III & $28(11.6)$ \\
\hline Unknown & 4 (1.7) \\
\hline \multicolumn{2}{|l|}{ ER } \\
\hline$<10 \%$ & $22(9.1)$ \\
\hline$\geq 10 \%$ & 220 (90.9) \\
\hline \multicolumn{2}{|l|}{ PR } \\
\hline$<10 \%$ & $85(35.1)$ \\
\hline$\geq 10 \%$ & 157 (64.9) \\
\hline \multicolumn{2}{|l|}{ Ki67 } \\
\hline$<10 \%$ & $66(27.3)$ \\
\hline$\geq 10 \%$ & $172(71.1)$ \\
\hline Unknown & $4(1.7)$ \\
\hline \multicolumn{2}{|l|}{ HER 2 IHC } \\
\hline Negative/moderate $(0-2+)$ & $208(85.9)$ \\
\hline Strong $(3+)$ & $27(11.2)$ \\
\hline Unknown & 7 (2.9) \\
\hline \multicolumn{2}{|l|}{ Event } \\
\hline NED & $197(81.4)$ \\
\hline Local recurrence & 10 \\
\hline Metastasis & $15(6.2)$ \\
\hline Contralateral tumour & $12(5.0)$ \\
\hline Death & $8(3.3)$ \\
\hline
\end{tabular}

ER, estrogen receptor; PR, progesterone receptor; HER2, human epidermal growth factor receptor 2 ; IHC, immunohistochemistry.

cancers. Although it exhibits a high degree of tumour-specific expression and is one of the 16 cancer-related genes included in the Oncotype DX assay (22), the role of survivin as a breast cancer biomarker has remained the subject of much debate. Previous studies using quantitative reverse transcriptionpolymerase chain reaction (qRT-PCR) and IHC have reported that survivin is either prognostically irrelevant or associated with improved or adverse outcome in primary breast cancer patients (23-25). Such discordant results could perhaps be explained by the fact that these studies did not account for subcellular localization of survivin, which can be present in both nuclear and cytoplasmatic pools. These different pools are immunochemically and functionally different and are independently modulated during the cell cycle (26). Furthermore, recent studies have demonstrated that increased expression of nuclear, as opposed to cytoplasmic, survivin was associated with decreased overall survival (OS) and breast cancer-specific survival (BCSS) $(27,28)$.

Testin (TES) is a putative tumour suppressor. The human TES gene is localised to the fragile site FRA7G at 7q31.2, and downregulation of TES has been reported in many human malignancies (29-33). In addition, a profound reduction in growth potential was detected in different cancer cell lines in which TES was overexpressed $(34,35)$. TES is a highly conserved protein of 421 amino acids containing three C-terminal LIM domains, which are responsible for proteinprotein interactions coordinating intracellular and extracellular pathways. In particular, TES is a component of the focal adhesion complex, which is important in the regulation of epithelial physiology and localises to cell-matrix adhesions, cell-cell contacts and actin stress fibres. In mice, TES interacts and colocalises with a variety of cytoskeletal proteins, including zyxin, mena, VASP, talin and actin $(36,37)$. Overexpression of TES decreased cell motility (36-38). Moreover, restoration of TES expression in breast cancer and uterine sarcoma cell lines inhibited their growth by induction of apoptosis (34). In association with alterations of cell adhesion and motility, TES expression resulted in activation of caspase-dependent and -independent apoptosis in the absence or with a reduced level of survivin (34).

Expression of TES and its relationship with survivin have never been evaluated in a large series of human breast tumours. The aim of this study was to determine whether TES and survivin expression could characterise the different breast cancer subtypes and their correlation with clinicopathological parameters.

\section{Materials and methods}

Patient samples. The study was carried out on 242 consecutive cases of breast carcinomas that were obtained from the Cantonal Institute of Pathology (Locarno, Switzerland). The study was approved by the Cantone Ticino Ethics Committee. All cases were diagnosed during the period from January 1981 to December 2009 with a median follow-up time of 5.2 years (SD, 3.4 years). The median age at diagnosis was 54.4 (SD, 12.0). The histological diagnosis was determined during routine pathological assessment. The tumours were graded according to the Scarff-Bloom Richardson classification as modified by Elston and Ellis (39). Staging at the time of diagnosis was based on the TNM system (40). The clinicopathological characteristics of the patients are listed in Table I. All patients underwent surgery \pm radiotherapy and systemic standard treatment. Survival data, including disease-free survival (DFS) and BCSS, were maintained on a prospective basis. DFS was defined as the interval (in months) from the 
date of the primary surgical treatment to the first loco-regional or distant recurrence and BCSS was defined as the time (in months) from the date of the primary surgical treatment to the time of death from breast cancer.

Tumour classification. Tumours were classified according to standard molecular subtypes as follows: luminal A type (154/242, 63.6\%), luminal B type (39/242, 16.1\%; in particular 24/242, 9.9\%, with both ER and PR positivity), HER2 overexpression type $(7 / 242,2.9 \%)$, and triple-negative type $(35 / 242$, $14.5 \%)$.

Immunohistochemistry. Sections $(3-\mu \mathrm{m})$ were cut from formalin-fixed paraffin-embedded (FFPE) blocks and mounted on positive-charged slides. Immunostaining was performed using anti-survivin rabbit polyclonal antibody (1:250, cat. ab469) and anti-TES mouse monoclonal antibody (1:200, cat. ab57292; both from Abcam, Cambridge, MA, USA). The specificity of both antibodies was previously confirmed by western blot analysis. Cell nuclei were counterstained with hematoxylin solution. Slides were evaluated by at least two investigators in a blinded manner. Positive samples for each antibody and negative samples, in which the primary antibody was omitted, were used as controls. Adjacent normal breast tissues in most samples served as the internal negative or positive control depending on the protein tested.

Data analysis. Immunostaining for survivin was recorded according to staining intensity, distribution in the cytoplasm and/or nucleus and the percentage of positive tumour cells. In cases where staining was heterogeneous in the slide, examined fields included those with the highest and lowest percentage of stained cells. A mean percentage of positive tumour cells was determined in at least five areas at a magnification of $x 400$. A tumour was assessed as survivin-positive if the staining was positive-cytoplasmatic, positive-nuclear or both. Staining was scored as follows: score 0 , no staining or staining in $<5 \%$ of cells; score 1 , weak staining in $6-19 \%$ of cells; score 2 , moderate staining in $20-40 \%$ of cells; score 3 , strong staining in $>40 \%$ of cells. For statistical analysis, scores 0 and 1 were considered negative, and scores 2 and 3 were considered positive for both cytoplasmatic and nuclear staining. Immunostaining for cytoplasmatic TES was scored as follows: score 0 , no staining or staining in $2 \%$ of cells; score $1,3-40 \%$ positively stained cells (weak staining); score $2,41-65 \%$ positively stained cells (moderate staining); score $3,>65 \%$ positively stained cells (strong staining).

Data on ER, PR, Ki67 and HER2/neu were obtained through standard clinical testing, using IHC for ER and PR and the Hercep Test ${ }^{\mathrm{TM}}$ (Dako, Glostrup, Denmark) for HER2/ neu. HER 2 staining was divided into two groups, with negative to moderate $(0-2+)$ HER2 expression and strong (3+) overexpression. Cases scoring 2+ for HER2 immunostaining were subsequently assessed by fluorescence in situ hybridisation study (FISH).

Statistical analysis. The statistical analysis was carried out using the semi-quantitative results of the immunohistochemical staining. A univariate statistical analysis was carried out using Chi-Square test and odds ratios (ORs) to analyse the categorical variables and the Student's t-test for independent samples to analyse continuous variables. The relationship between 'survivin overexpression and TES downregulation' with 'triple-negative phenotype' was also studied in the multivariate analysis, taking into account the effect of the confounding variable 'histological grade', using a binary logistic model. Continuous data were tested for normality. The analysis of time to event was performed using Kaplan-Meier methodology. Statistical significance was defined as a value of $\mathrm{P}=0.05$, two-tailed. All statistical analyses were performed using PASW Statistics 19 (formerly SPSS 19).

\section{Results}

Expression of survivin and TES in breast tissues. Cytoplasmatic or nuclear survivin expression was detected in $97 \%$ of the breast carcinomas. No expression of survivin was observed in the adjacent normal breast tissues, with the exception of a few samples where the normal breast tissues showed cytoplasmic positivity. The above percentage was within the range of previously published studies $(17,18,41)$. Positive nuclear staining of survivin was found in $9 / 242$ of the breast tumours (3.7\%; score 2 and 3), while positive cytoplasmic staining was present in $22.3 \%$ of the cases (54/242). In 172 out of 242 (71\%) patients there was positive staining both in the nucleus and in the cytoplasm (Fig. 1). These results are in accordance with previous studies (42).

Reduced TES expression was found in $74.7 \%$ of the cases (181/242). Tumours were divided into three different categories: no staining, weak staining and moderate staining (score 0,1 and 2, respectively) (Fig. 2). The adjacent normal breast tissues with surrounding mesenchymal and endothelial cells showed specific immunoreactivity and represented an internal positive control for TES antibody specificity.

Correlation between survivin and TES expression and clinical outcome of breast cancer patients. From a clinical perspective, we assessed the correlation between survivin and TES expression and clinicopathological parameters in the primary breast cancers (Table II). TES status, alone and in association with nuclear expression of survivin, was significantly correlated with increased histological grade, being predominantly present in grade III tumours ( $\mathrm{P}=0.004$ and 0.003 , respectively). There was also a statistically significant correlation between high nuclear survivin expression $(>40 \%$ of tumour cells) and the presence of lymph node metastases $(\mathrm{P}=0.09)$. There was no significant association between nuclear and/or cytoplasmic survivin expression, TES expression and age of patients, histological type (ductal or lobular) and HER2 status. However, there was a trend toward a significant association between absent or weak expression of TES and Ki67 expression $(\mathrm{P}=0.055)$. The results of the $\chi^{2}$ analysis of these data are summarised in Table II.

On account of the short median follow-up time of 5.2 years, Kaplan-Meier survival analysis did not reveal any association between survivin and TES expression and BCSS or DFS. However, we found a higher percentage of events (i.e. local recurrence, distant metastases and death) in cases with positive nuclear survivin expression (22.2 vs. $11.3 \%, \mathrm{P}=0.039)$ and low TES expression (23.8 vs. $14.6 \%, \mathrm{P}=0.068$ ) (Tables I and III). 

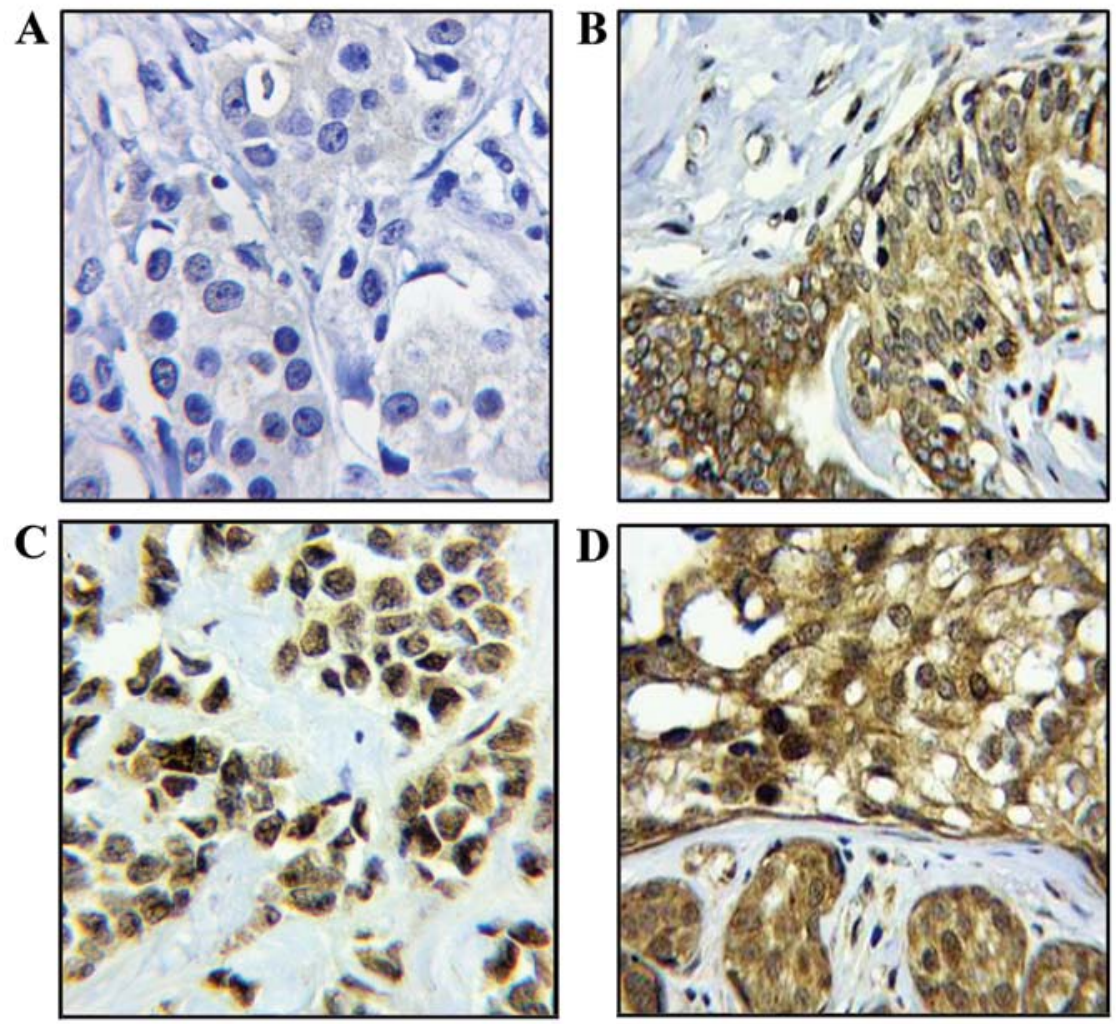

Figure 1. Representative images of the results of survivin IHC (magnification, $\mathrm{x} 400$ ). (A) Negative cytoplasmatic and nuclear expression of survivin. (B) Positive cytoplasmatic expression of survivin. (C) Positive nuclear expression of survivin. (D) Positive cytoplasmatic and nuclear expression of survivin.
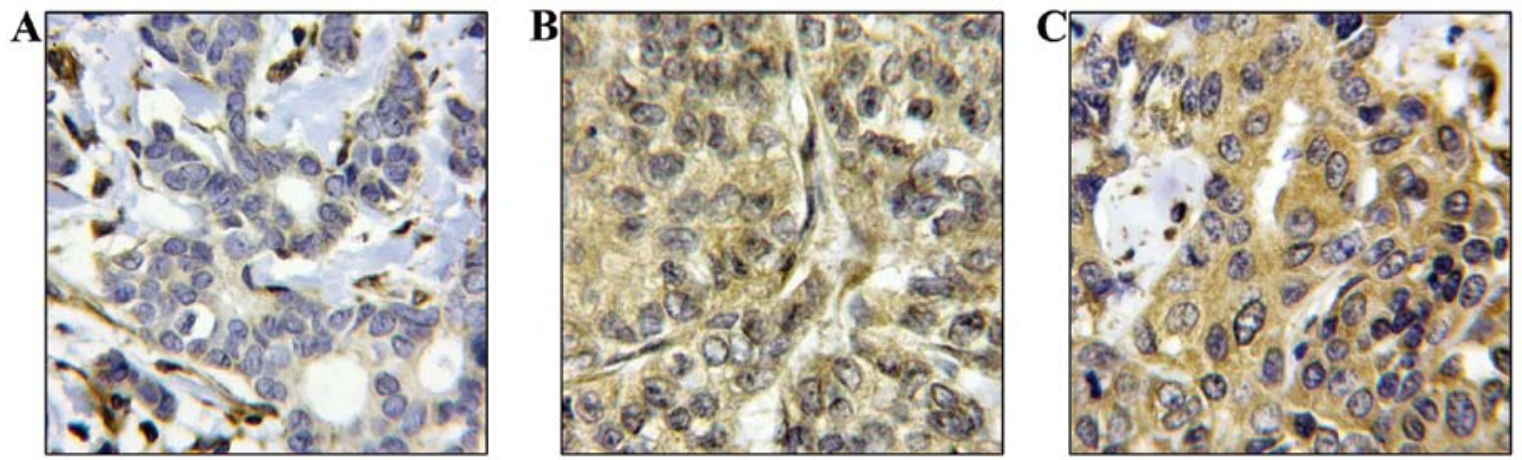

Figure 2. Representative images of TES IHC (magnification, $x 400$ ). (A) Negative cytoplasmatic expression of TES. (B) Weak cytoplasmatic expression of TES. (C) Moderate cytoplasmatic expression of TES.
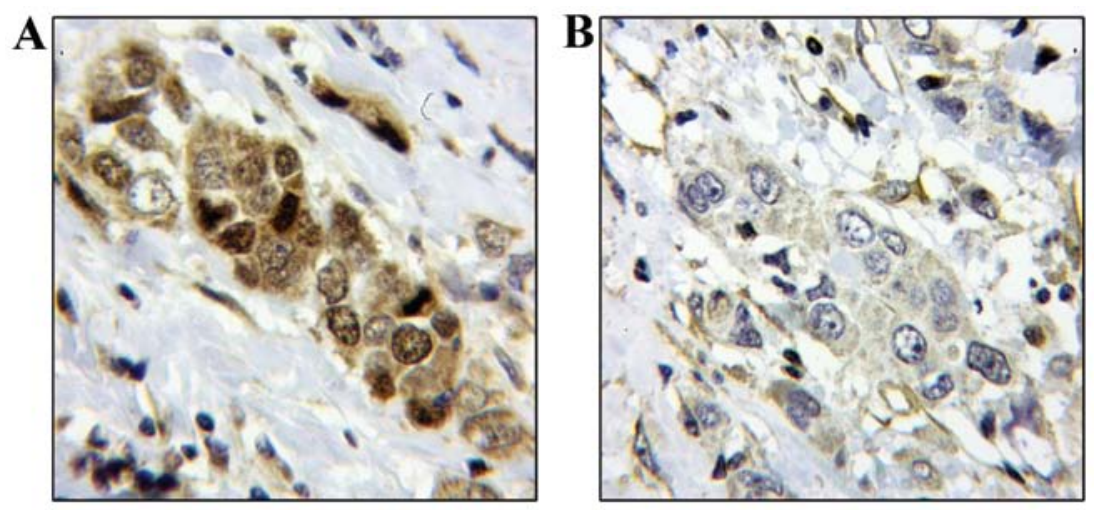

Figure 3. Triple-negative subtype staining. (A) Triple-negative breast cancer with nuclear and cytoplasmatic expression of survivin and (B) negative expression of TES (magnification, $\mathrm{x} 400$ ). 
Table II. Relationship between survivin and TES expression and standard clinicopathological and immunohistochemical markers.

\begin{tabular}{|c|c|c|c|c|c|c|}
\hline Parameter & $\begin{array}{l}\text { Nuclear survivin } \\
\text { high expression } \\
\text { (score } 2-3) \\
\mathrm{n}(\%)\end{array}$ & $\begin{array}{c}\text { Chi-square } \\
\text { P-value }\end{array}$ & $\begin{array}{c}\text { TES } \\
\text { negative/low/ } \\
\text { reduced expression } \\
(\text { score } 0-2) \\
\mathrm{n}(\%)\end{array}$ & $\begin{array}{c}\text { Chi-square } \\
\text { P-value }\end{array}$ & $\begin{array}{c}\text { Association of } \\
\text { survivin (score 2-3) } \\
\text { and TES (score 0-2) } \\
\mathrm{n}(\%)\end{array}$ & $\begin{array}{c}\text { Chi-square } \\
\text { P-value }\end{array}$ \\
\hline \multicolumn{7}{|l|}{ Grade } \\
\hline 1 & $15 / 32 \quad(46.9)$ & $0.097 \mathrm{NS}$ & $19 / 32 \quad(59.4)$ & 0.004 & $13 / 32 \quad(40.6)$ & 0.003 \\
\hline 2 & $60 / 122(49.2)$ & & $87 / 122(71.3)$ & & $67 / 122(54.9)$ & \\
\hline 3 & $45 / 87 \quad(51.7)$ & & $75 / 87 \quad(86.2)$ & & $63 / 87 \quad(72.4)$ & \\
\hline \multicolumn{7}{|c|}{$\begin{array}{l}\text { Histological } \\
\text { nodal status }\end{array}$} \\
\hline Negative & $57 / 134(42.5)$ & 0.009 & $54 / 134(40.3)$ & $0.224 \mathrm{NS}$ & $78 / 134(58.2)$ & $0.814 \mathrm{NS}$ \\
\hline Positive & $62 / 104(59.6)$ & & $51 / 104(49)$ & & $63 / 104(60.6)$ & \\
\hline \multicolumn{7}{|l|}{ Ki67 } \\
\hline$<10$ & $45 / 66 \quad(68.2)$ & $0.146 \mathrm{NS}$ & $22 / 66 \quad(33.3)$ & $0.055 \mathrm{NS}$ & $33 / 66 \quad(50)$ & $0.087 \mathrm{NS}$ \\
\hline$\geq 10$ & $133 / 172(77.3)$ & & $81 / 172(47.1)$ & & $107 / 172(62.2)$ & \\
\hline
\end{tabular}

TES, testin; NS, not significant.

Table III. Correlation of survivin and TES expression with event incidence.

\begin{tabular}{lcccccc}
\hline & $\begin{array}{c}\text { Survivin } \\
\text { high expression } \\
\text { (score 2-3) } \\
\mathrm{n}(\%)\end{array}$ & $\begin{array}{c}\text { Survivin negative } \\
\text { or low expression } \\
\text { (score 0-1) } \\
\mathrm{n}(\%)\end{array}$ & $\begin{array}{c}\text { Chi-square } \\
\text { P-value }\end{array}$ & $\begin{array}{c}\text { TES negative/ } \\
\text { low expression } \\
\text { (score 0-1) } \\
\mathrm{n}(\%)\end{array}$ & $\begin{array}{c}\text { TES moderate/ } \\
\text { strong expression } \\
\text { (score 2-3) } \\
\mathrm{n}(\%)\end{array}$ & $\begin{array}{c}\text { Chi-square } \\
\text { P-value }\end{array}$ \\
\hline Event incidence & $\begin{array}{c}36 / 162(22.2) \\
\text { NED }\end{array}$ & $\begin{array}{c}9 / 80(11.3) \\
71 / 80(162)\end{array}$ & 0.039 & $\begin{array}{c}25 / 105(23.8) \\
80 / 105(76.2)\end{array}$ & $\begin{array}{r}20 / 137(14.6) \\
117 / 137(85.4)\end{array}$ & 0.068 NS \\
\hline
\end{tabular}

TES, testin.

Association of survivin and TES expression with breast cancer subtypes. The prognostic implications of breast cancer subtypes have been described in several reports. We found a statistically significant association between the subcellular localization of survivin (moderate/strong nuclear staining with or without cytoplasmic staining), reduced TES expression (score 0-2) and the triple-negative breast cancer subtype $(\mathrm{P}=0.009)$ (univariate OR, 3.20; 95\% CI, 1.34-7.66) (Fig. 3). There was also a significant association between nuclear survivin expression and the triple-negative subtype $(\mathrm{P}=0.022)$ (univariate $\mathrm{OR}, 4.15$; $95 \%$ CI, 1.22-14.1). A multivariate analysis based on a binary logistic model was carried out, using the variable 'survivin overexpression and TES downregulation' as the dependent one and 'histological grade' as well as 'triple-negative phenotype' as covariates. The histological grade was dichotomised into high (grade 2 and 3) and low (grade 1). Triple-negative phenotype exhibited a statistically significant result $[\mathrm{P}=0.018$; OR, 2.90; 95\% CI, 1.2-6.97 (reference group = no triple phenotype)], while the histological grade exhibited borderline significance $[\mathrm{P}=0.051$; OR, 2.15; 95\% CI, 0.997-4.62 (reference group $=$ low histological grade)]. These results showed a significant association between the triple-negative phenotype and survivin overexpression and TES downregulation, independently of the histological grade. Furthermore, there was a significant correlation between the absence or low expression of TES (immunohistochemical score 0-1) and the luminal B subtype with $\mathrm{ER}^{+}$and $\mathrm{PR}^{+}$expression $(\mathrm{P}=0.019)$ (univariate $\mathrm{OR}$, $2.9 ; 95 \% \mathrm{CI}, 1.19-7.06)$, independently of the histological grade (adjusted multivariate OR, 2.67; 95\% CI, 1.09-6.65; $\mathrm{P}=0.032$ ) (Fig. 4). These data are summarised in Table IV. Instead, there was no significant association between cytoplasmic and/or nuclear survivin expression, absence or downregulation of TES and the luminal A and HER2 subtypes.

\section{Discussion}

Advances in high-throughput methodologies have revolutionised the scientific approach to highly complex diseases. Breast cancer subtypes have been extensively characterised by gene expression analysis using microarrays. However, this approach is not feasible for large-scale clinical applications or retrospective studies using FFPE tissue samples. In 
Table IV. Correlation between survivin and TES expression and breast cancer molecular subtypes.

\begin{tabular}{|c|c|c|c|c|c|c|}
\hline $\begin{array}{l}\text { Subtype } \\
\mathrm{n}(\%)\end{array}$ & $\begin{array}{l}\text { Nuclear survivin } \\
\text { high expression } \\
\text { (score } 2-3) \\
n(\%)\end{array}$ & $\begin{array}{l}\text { Fisher test } \\
\text { P-value }\end{array}$ & $\begin{array}{l}\text { TES negative/low/ } \\
\text { reduced expression } \\
(\text { score } 0-2) \\
\mathrm{n}(\%)\end{array}$ & $\begin{array}{l}\text { Fisher test } \\
\text { P-value }\end{array}$ & $\begin{array}{c}\text { Association of } \\
\text { survivin (score } 2-3) \\
\text { and TES (score } 0-2) \\
n(\%)\end{array}$ & $\begin{array}{c}\text { Fisher test } \\
\text { P-value }\end{array}$ \\
\hline \multirow{4}{*}{$\begin{array}{l}\text { Triple-negative } \\
35 / 242(14.89)\end{array}$} & $32 / 35(91.4)$ & 0.012 & 29/35 (82.9) & $0.295 \mathrm{NS}$ & $28 / 35(80.0)$ & 0.009 \\
\hline & $\begin{array}{c}\text { vs. } \\
149 / 207(72.0)\end{array}$ & & $\begin{array}{c}\text { Vs. } \\
152 / 207(73.4)\end{array}$ & & $\begin{array}{c}\text { Vs. } \\
115 / 207(55.6)\end{array}$ & \\
\hline & $\begin{array}{c}\text { Univariate } \\
\text { OR=4.15 } \\
95 \% \text { CI, } 1.22-14.1\end{array}$ & 0.022 & $\begin{array}{c}\text { Univariate } \\
\text { OR=1.75 } \\
95 \% \text { CI, } 0.69-4.44\end{array}$ & $0.24 \mathrm{NS}$ & $\begin{array}{c}\text { Univariate } \\
\text { OR=3.20 } \\
95 \% \text { CI, } 1.34-7.66\end{array}$ & 0.009 \\
\hline & $\begin{array}{c}\text { Adjusted }^{\mathrm{a}} \\
\text { OR=4.07 } \\
95 \% \mathrm{CI}, 1.19-13.88\end{array}$ & 0.025 & $\begin{array}{c}\text { Adjusted }^{\mathrm{a}} \\
\text { OR=1.54 } \\
95 \% \text { CI, 0.60-3.95 }\end{array}$ & $0.37 \mathrm{NS}$ & $\begin{array}{c}\text { Adjusted }^{\mathrm{a}} \\
\text { OR }^{2.90} \\
95 \% \text { CI, } 1.20-6.97\end{array}$ & 0.018 \\
\hline \multirow[t]{3}{*}{$\begin{array}{l}\text { Luminal B } \\
24 / 242(9.9)\end{array}$} & $\begin{array}{c}17 / 24(70.8) \\
\text { vs. } \\
164 / 218(75.2)\end{array}$ & $0.63 \mathrm{NS}$ & $\begin{array}{c}16 / 24(66.6) \\
\text { vs. } \\
89 / 218(40.8)\end{array}$ & 0.018 & $\begin{array}{c}15 / 24(62.5) \\
\text { vs. } \\
128 / 218(58.7)\end{array}$ & $0.83 \mathrm{NS}$ \\
\hline & $\begin{array}{c}\text { Univariate } \\
\text { OR }=0.80 \\
95 \% \text { CI, } 0.32-2.03\end{array}$ & $0.64 \mathrm{NS}$ & $\begin{array}{c}\text { Univariate } \\
\text { OR=2.90 } \\
95 \% \mathrm{CI}, 1.19-7.06\end{array}$ & 0.019 & $\begin{array}{c}\text { Univariate } \\
\text { OR }=1.17 \\
95 \% \text { CI, } 0.49-2.80\end{array}$ & $0.72 \mathrm{NS}$ \\
\hline & $\begin{array}{c}\text { Adjusted }^{\mathrm{a}} \\
\text { OR=0.77 } \\
95 \% \text { CI, } 0.30-1.98\end{array}$ & $0.59 \mathrm{NS}$ & $\begin{array}{c}\text { Adjusted }^{\mathrm{a}} \\
\text { OR=2.67 } \\
95 \% \mathrm{CI}, 1.09-6.65\end{array}$ & 0.032 & $\begin{array}{c}\text { Adjusted }^{\mathrm{a}} \\
\text { OR=1.06 } \\
95 \% \mathrm{CI}, 0.44-2.55\end{array}$ & $0.90 \mathrm{NS}$ \\
\hline
\end{tabular}

${ }^{a}$ OR adjusted for the effect of the confounding variable 'histological grade'. Luminal B, ER/PgR/HER2 ${ }^{+}$. TES, testin; OR, odds ratio; ER, estrogen receptor; HER2, human epidermal growth factor receptor 2. NS, not significant.
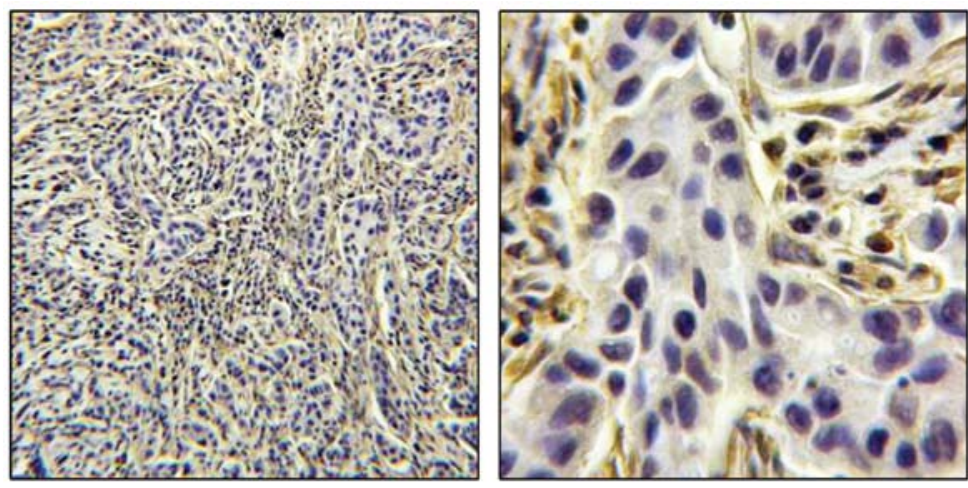

Figure 4. Luminal B subtype staining. Luminal B breast cancer (ER/PgR/HER2+) with negative expression of TES (magnification: x100, left panel; $x 400$, right panel).

these situations immunohistochemical staining for specific biomarkers provides a useful alterative. In the present study, we showed that decreased expression of TES and increased levels of nuclear survivin were preferentially associated with the triple-negative subtype. This subtype generally presents high histological grade, Ki67 overexpression and unfavourable prognosis.

Survivin is a bifunctional protein, which is both an integral component of the chromosome passenger complex and a negative regulator of apoptosis. Survivin exists in distinct intracellular pools. The predominant cytosolic fraction and a smaller nuclear pool are independently modulated during cell cycle progression and control the assembly of a normal bipolar mitotic apparatus (43). More importantly, cytoplasmic localisation of survivin in non-malignant cells suppresses apoptosis, while nuclear translocation may be important to regulate proliferation (44). Survivin intracellular localisation is regulated by an active and evolutionarily conserved, Crm1-dependent nuclear export signal, which appears to be essential for survivin tumour-promoting functions. In particular, inhibition of this signal abrogates the anti-apoptotic effect of survivin, while maintains its mitotic activity. This suggests 
that increased levels of nuclear survivin lead to a proliferative aggressive phenotype $(28,45,46)$. However, the exact prognostic and clinical implications of the nuclear or cytoplasmatic localisation of survivin remain controversial. Here, we found that nuclear survivin is a predictor of worse outcome in breast cancer and a strong association between nuclear survivin and the triple-negative breast cancer subtype.

Based on the results of our previous study on TES in breast cancer cell lines (34), we assessed the pattern of TES expression in breast tumours to determine whether reduced expression of TES would be preferentially associated with specific tumour subgroups. We found that TES was expressed in ducts and lobules of normal breast. In particular, TES was present in epithelial, myoepithelial and basal cells in normal tissues. TES was significantly reduced in tumour cells in a large fraction of the breast cancers. In some breast tumours with adjacent normal tissues with hyperplastic foci, TES was detected only in the normal myoepithelial and basal cells. Negative expression of TES in the columnar cells is likely to be the result of dysplastic transformation of the breast epithelium. However, the significance of this particular localisation warrants investigation, as it suggests that the pattern of expression of TES is more complex than originally believed. TES was also abundantly expressed in the stroma and endothelial cells (47) surrounding both normal and tumour tissues. Remarkably, we found a significant correlation between TES downregulation, together with nuclear survivin expression, and the triplenegative subtype. In contrast, regardless of survivin, negative or very weak expression of TES was strongly correlated with the luminal $\mathrm{B}$ subtype, $\mathrm{ER}^{+}$and $\mathrm{PR}^{+}$tumours.

Tumourigenesis is a multistep process resulting from the accumulation of genetic and epigenetic changes $(48,49)$. DNA methylation, a major epigenetic modification, leads to gene silencing. The frequency of hypermethylation of $\mathrm{CpG}$ dinucleotides varies significantly between breast cancer subtypes (50). $\mathrm{CpG}$ islands were found to be more frequently methylated in luminal B tumours than in the other tumour subtypes (50). Furthermore, depending on ER status and irrespective of the molecular subtype, a higher methylation frequency was observed in $\mathrm{ER}^{+}$and $\mathrm{PR}^{+}$tumours (50). The human TES gene is located in the fragile chromosomal region FRA7G. Common fragile sites are regions in mammalian chromosomes prone to breakage and rearrangements. This genetic instability can lead to disease manifestations and may play a role in oncogenesis (51). FRA7G is a locus of $300 \mathrm{~kb}$, localised between markers D7S486 and D7S522, which shows loss of heterozygosity in many human malignancies $(52,53)$. This region is known to encompass several genes, in addition to TES, including caveolin-1, caveolin-2 (54) and MET (55). The methylation of $\mathrm{CpG}$ in the TES promoter is a frequent event in gastric tumours (32). In previous studies, methylation of the TES promoter was also shown to be common in breast cancer $(30,34)$ and may be involved in TES downregulation. The different correlation of TES in regards to triple-negative and luminal B subtypes could be linked to a different grade of hypermethylation of $\mathrm{CpG}$ islands in the TES promoter region (50).

TES is an important structural protein and may serve as a platform to integrate multiple signal transduction events. Current data suggest the possibility that downregulation of TES is associated with alterations in cell adhesion and motility and therefore can lead to development of tumours with an aggressive phenotype. The reduced expression of TES in tumours of the basal-like/triple-negative subtype, along with its expression in myoepithelial/basal cells of the normal breast, can lead to speculate a possible role in epithelial-to-mesenchymal transition (EMT). EMT is an important process associated with the ability of epithelial cells to detach from a primary tumour and metastasise. It is also possible that the tumour-suppressive function of TES may reside within alternative, yet unknown functions. A possible function of TES in survivin-dependent pathways may stem from maintenance of a basal/myoepithelial phenotype in basal-like/triple-negative breast cancer, as it has been noted for caveolin 1 and $2(56,57)$.

Reduced expression of TES characterises breast cancer subtypes with particularly poor outcome such as triple-negative and luminal B tumours, and therefore can be considered an important marker to aid in predicting the course of disease, either by itself or in association with established markers, such as survivin. Further studies generating long-term follow-up data are warranted to confirm the usefulness of TES as a biomarker in breast cancer. Furthermore, a greater understanding of the molecular and functional role of TES in aggressive types of breast cancer may lead to more selective and effective treatment for breast cancer patients.

\section{Acknowledgements}

We thank Professor Luca Mazzucchelli, Dr Milo Frattini and Dr Jessica Barizzi for the FFPE tissue sections of human breast cancer and for their advice in the immunohistochemical analysis. This study was supported by the Fondazione Ticinese per la Ricerca sul Cancro (Lugano, Switzerland).

\section{References}

1. Span PN, Sweep FC, Wiegerinck ET, Tjan-Heijnen VC, Manders P, Beex LV and deKok JB: Survivin is an independent prognostic marker for risk stratification of breast cancer patients. Clin Chem 50: 1986-1993, 2004.

2. The International Agency for Research on Cancer (IARC): Pathology and Genetics: Tumours of the Breast and Female Genital Organs. In: World Health Organization Classification of Tumours. Volume 4. 3rd edition. Tavassoli FA and Devilee P (eds.), IARC Press, Lyon, 2003.

3. Page DL: Special types of invasive breast cancer, with clinical implications. Am J Surg Pathol 27: 832-835, 2003.

4. Weigelt B, Horlings HM, Kreike B, Hayes MM, Hauptmann M, Wessels LF, de Jong D, Van de Vijver MJ, Van't Veer LJ and Peterse JL: Refinement of breast cancer classification by molecular characterization of histological special types. J Pathol 216: 141-150, 2008.

5. Sørlie T, Perou CM, Tibshirani R, Aas T, Geisler S, Johnsen H, Hastie T, Eisen MB, van de Rijn M, Jeffrey SS, Thorsen T, Quist H, Matese JC, Brown PO, Botstein D, Lønning PE and Børresen-Dale AL: Gene expression patterns of breast carcinomas distinguish tumor subclasses with clinical implications. Proc Natl Acad Sci USA 98: 10869-10874, 2001.

6. Nielsen TO, Hsu FD, Jensen K, Cheang M, Karaca G, Hu Z, Hernandez-Boussard T, Livasy C, Cowan D, Dressler L, Akslen LA, Ragaz J, Gown AM, Gilks CB, van de Rijn M and Perou CM: Immunohistochemical and clinical characterization of the basal-like of invasive breast carcinoma. Clin Cancer Res 10: 5367-5374, 2004.

7. Banerjee S, Reis-Filho JS, Ashley S, Steele D, Ashworth A, Lakhani SR and Smith IE: Basal-like breast carcinomas: clinical outcome and response to chemotherapy. J Clin Pathol 59: 729-735, 2006. 
8. Cheang MC, Voduc D, Bajdik C, Leung S, McKinney S, Chia SK, Perou CM and Nielsen TO: Basal-like breast cancer defined by five biomarkers has superior prognostic value than triple-negative phenotype. Clin Cancer Res 14: 1368-1376, 2008.

9. Laurinavicius A, Laurinaviciene A, Ostapenko V, Dasevicius D, Jarmalaite $S$ and Lazutka J: Immunohistochemistry profiles of breast ductal carcinoma: factor analysis of digital image analysis data. Diagn Pathol 7: 27, 2012.

10. Carey LA, Perou CM, Livasy CA, Dressler LG, Cowan D, Conway K, Karaca G, Troester MA, Tse CK, Edmiston S, Deming SL, Geradts J, Cheang MC, Nielsen TO, Moorman PG, Earp HS and Millikan RC: Race, breast cancer subtypes, and survival in the Carolina Breast Cancer Study. JAMA 295 2492-2502, 2006.

11. Morrison DH, Rahardja D, King E, Peng Y and Sarode VR: Tumour biomarker expression relative to age and molecular subtypes of invasive breast cancer. Br J Cancer 107: 382-387, 2012.

12. Geyer FC, Rodrigues DN, Weigelt B and Reis-Filho JS: Molecular classification of estrogen receptor-positive/luminal breast cancer. Adv Anat Pathol 19: 39-53, 2012.

13. Bertucci F, Finetti P, Cervera N, Esterni B, Hermitte F, Viens P and Birnbaum D: How basal are triple-negative breast cancers? Int J Cancer 123: 236-240, 2008

14. de Ruijter TC, Veeck J, de Hoon JP, van Engeland M and Tjan-Heijnen VC: Characteristics of triple-negative breast cancer. J Cancer Res Clin Oncol 137: 183-192, 2011.

15. Nakagawa M, Bando Y, Nagao T, Takai C, Ohnishi T, Honda J, Moriya T, Izumi K, Takahashi M, Tangoku A and Sasa M: Among triple-negative breast cancers, HER2 (0) breast cancer shows a strong tendency to be basal-like compared with HER2 (1+) breast cancer: preliminary results. Breast Cancer 19: 54-59, 2012.

16. Duffy MJ, O'Donovan N, Brennan DJ, Gallagher WM and Ryan BM: Survivin: a promising tumor biomarker. Cancer Lett 249: 49-60, 2007.

17. Adamkov M, Halasova E, Kajo K, Machalekova K, Vybohova D, Varga I and Rajcany J: Survivin: a promising biomarker in breast carcinoma. Neoplasma 57: 572-577, 2010.

18. Nassar A, Sexton D, Cotsonis G and Cohen C: Survivin expression in breast carcinoma: correlation with apoptosis and prognosis. Appl Immunohistochem Mol Morphol 16: 221-226, 2008 .

19. Dallaglio K, Marconi A and Pincelli C: Survivin: a dual player in healthy and diseased skin. J Invest Dermatol 132: 18-27, 2012.

20. Ambrosini G, Adida C and Altieri DC: A novel anti-apoptosis gene, survivin, espressed in cancer and lynphoma. Nat Med 3 : 917-921, 1997.

21. Nassar A, Lawson D, Cotsonis G and Cohen C: Survivin and caspase-3 expression in breast cancer: correlation with prognostic parameters, proliferation, angiogenesis, and outcome. Appl Immunohistochem Mol Morphol 16: 113-120, 2008.

22. Paik S, Shak S, Tang G, Kim C, Baker J, Cronin M, Baehner FL, Walker MG, Watson D, Park T, Hiller W, Fisher ER Wickerham DL, Bryant $\mathrm{J}$ and Wolmark N: A multigene assay to predict recurrence of tamoxifen-treated, node-negative breast cancer. N Engl J Med 351: 2817-2826, 2004.

23. Chu JS, Shew JY and Huang CS: Immunohistochemical analysis of survivin espression in primary breast cancers. J Formos Med Assoc 103: 925-931, 2004.

24. Kennedy SM, O'Driscoll L, Purcell R, Fitz-Simons N, McDermott EW, Hill AD, O'Higgins NJ, Parkinson $M$, Linehan R and Clynes M: Prognostic importance of survivin in breast cancer. Br J Cancer 88: 1077-1083, 2003.

25. Hinnis AR, Luckett JC and Walker RA: Survivin is an independent predictor of short-term survival in poor prognostic breast cancer patients. Br J Cancer 96: 639-645, 2007.

26. Caldas H, Jiang Y, Holloway MP, Fangusaro J, Mahotka C, Conway EM and Altura RA: Survivin splice variants regulate the balance between proliferation and cell death. Oncogene 24 1994-2007, 2005.

27. Brennan DJ, Rexhepaj E, O'Brien SL, McSherry E, O'Connor DP, Fagan A, Culhane AC, Higgins DG, Jirstrom K, Millikan RC, Landberg G, Duffy MJ, Hewitt SM and Gallagher WM: Altered cytoplasmic-to-nuclear ratio of survivin is a prognostic indicator in breast cancer. Clin Cancer Res 14: 2681-2689, 2008.

28. Rexhepaj E, Jirstrom K, O'Connor DP, O'Brien SL, Landberg G, Duffy MJ, Brennan DJ and Gallagher WM: Validation of cytoplasmic-to-nuclear ratio of survivin as an indicator of improved prognosis in breast cancer. BMC Cancer 10: 639, 2010.
29. Gunduz E, Gunduz M, Beder L, Nagatsuka H, Fukushima K, Sutcu R, Delibas N, Yamanaka N, Shimizu K and Nagai N: Downregulation of TESTIN and its association with cancer history and a tendency toward poor survival in head and neck squamous cell carcinoma. Arch Otolaryngol Head Neck Surg 135: 254-260, 2009.

30. Tatarelli C, Linnenbach A, Minori $\mathrm{K}$ and Croce CM: Characterization of the human TESTIN gene localized in the FRA7G region at 7q31.2. Genomics 68: 1-12, 2000.

31. Weeks RJ, Kees UR, Song S and Morison IM: Silencing of TESTIN by dense biallelic promoter methylation is the most common molecular event in childhood acute lymphoblastic leukaemia. Mol Cancer 9: 163, 2010.

32. Ma H, Weng D, Chen Y, Huang W, Pan K, Wang H, Sun J, Wang Q, Zhou Z, Wang $\mathrm{H}$ and Xia J: Extensive analysis of D7S486 in primary gastric cancer supports TESTIN as a candidate tumor suppressor gene. Mol Cancer 9: 190, 2010.

33. Liu X, Cicek MS, Plummer SJ, Jorgenson E, Casey G and Witte JS: Association of testis derived transcript gene variants and prostate cancer risk. J Urol 177: 894-898, 2007.

34. Sarti M, Sevignani C, Calin GA, Aqeilan R, Shimizu M, Pentimalli F, Picchio MC, Godwin A, Rosenberg A, Drusco A, Negrini $M$ and Croce CM: Adenoviral transduction of TESTIN gene into breast and uterine cancer cell lines promotes apoptosis and tumor reduction in vivo. Clin Cancer Res 11: 806-813, 2005.

35. Tobias ES, Hurlstone AF, Mackenzie E, McFarlane R and Black DM: The TES gene at 7q31.1 is methylated in tumours and encodes a novel growth-suppressing LIM domain protein. Oncogene 20: 2844-2853, 2001.

36. Coutts AS, MacKenzie E, Griffith E and Black DM: TES is a novel focal adhesion protein with a role in cell spreading. J Cell Sci 116: 897-906, 2003.

37. Griffith E, Coutts AS and Black DM: RNAi knockdown of the focal adhesion protein TES reveals its role in actin stress fibre organisation. Cell Motil Cytoskeleton 60: 140-152, 2005.

38. Griffith E, Coutts AS and Black DM: Characterisation of chicken TES and its role in cell spreading and motility. Cell Motil Cytoskeleton 57: 133-142, 2004.

39. Elston CW and Ellis IO: Pathological prognostic factors in breast cancer. I. The value of histological grade in breast cancer: experience from a large study with long-term follow-up. Histopathology 41: 154-161, 2002.

40. Union Internationale Contre Cancer; International Union Against Cancer: TNM Atlas. 5th edition, Wittekind $\mathrm{CH}$, Hutter R, Greene FL, Klimpfinger M and Sobin LH (eds.). Springer-Verlag, Berlin, 2005.

41. Jha K, Shukla M and Pandey M: Survivin expression and targeting in breast cancer. Surg Oncol 21: 125-131, 2012.

42. Al-Joudi FS, Iskandar ZA, Hasnan J, Rusli J, Kamal Y Imran AK, Ahmed $\mathrm{M}$ and Zakaria J: Expression of survivin and its clinicopathological correlations in invasive ductal carcinoma of the breast. Singapore Med J 48: 607-614, 2007.

43. Fortugno P, Wall NR, Giodini A, O'Connor DS, Plescia J, Padgett KM, Tognin S, Marchisio PC and Altieri DC: Survivin exists in immunochemically distinct subcellular pools and is involved in spindle microtubule function. J Cell Sci 115: 575-585, 2002.

44. Moon WS and Tarnawski AS: Nuclear translocation of survivin in hepatocellular carcinoma: a key to cancer cell growth? Hum Pathol 34: 1119-1126, 2003.

45. Knauer SK, Krämer OH, Knösel T, Engels K, Rödel F, Kovács AF, Dietmaier W, Klein-Hitpass L, Habtemichael N, Schweitzer A, Brieger J, Rödel C, Mann W, Petersen I, Heinzel T and Stauber RH: Nuclear export is essential for the tumorpromoting activity of survivin. FASEB J 21: 207-216, 2007.

46. Stauber RH, Mann W and Knauer SK: Nuclear and cytoplasmic survivin: molecular mechanism, prognostic, and therapeutic potential. Cancer Res 67: 5999-6002, 2007.

47. Archacki SR, Angheloiu G, Moravec CS, Liu H, Topol EJ and Wang QK: Comparative gene expression analysis between coronary arteries and internal mammary arteries identifies a role for the TES gene in endothelial cell functions relevant to coronary artery disease. Hum Mol Genet 21: 1364-1373, 2012.

48. Jaenisch R and Bird A: Epigenetic regulation of gene expression: how the genome integrates intrinsic and environmental signals. Nat Genet 33: 245-254, 2003.

49. Dworkin AM, Huang TH and Toland AE: Epigenetic alterations in breast: implications for breast cancer detection, prognosis and treatment. Semin Cancer Biol 19: 165-171, 2009. 
50. Holm K, Hegardt C, Staaf J, Vallon-Christersson J, Jönsson G, Olsson H, Borg A and Ringnér M: Molecular subtypes of breast cancer are associated with characteristic DNA methylation patterns. Breast Cancer Res 12: R36, 2010.

51. Hellman A, Zlotorynski E, Scherer SW, Cheung J, Vincent JB, Smith DI, Trakhtenbrot L and Kerem B: A role for common fragile site induction in amplification of human oncogenes. Cancer Cell 1: 89-97, 2002.

52. Huang H, Qian J, Proffit J, Wilber K, Jenkins R and Smith DI: FRA7G extends over a broad region: coincidence of human endogenous retroviral sequences (HERV-H) and small polydispersed circular DNAs (spcDNA) and fragile sites. Oncogene 16: 2311-2319, 1998.

53. Huang H, Qian C, Jenkins RB and Smith DI: Fish mapping of YAC clones at human chromosomal band 7q31.2: identification of YACS spanning FRA7G within the common region of $\mathrm{LOH}$ in breast and prostate cancer. Genes Chromosomes Cancer 21: $152-159,1998$.
54. Elgelmann JA, Zhang XL and Lisanti MP: Genes encoding human caveolin-1 and -2 are co-localized to the D7S522 locus (7q31.1), a known fragile site (FRA7G) that is frequently deleted in human cancers. FEBS Lett 436: 403-410, 1998.

55. Lin JC, Scherer SW, Tougas L, Traverso G, Tsui LC, Andrulis IL, Jothy $S$ and Park M: Detailed deletion mapping with a refined physical map of $7 \mathrm{q} 31$ localizes a putative tumor suppressor gene for breast cancer in the region of MET. Oncogene 13: 2001-2008, 1996.

56. Elsheikh SE, Green AR, Rakha EA, Samaka RM, Ammar AA, Powe D, Reis-Filho JS and Ellis IO: Caveolin 1 and Caveolin 2 are associated with breast cancer basal-like and triple-negative immunophenotype. Br J Cancer 99: 327-334, 2008.

57. Mercier I, Bryant KG, Sotgia F, Bonuccelli G, Witkiewicz AK, Dasgupta A, Jasmin JF, Pestell RG and Lisanti MP: Using Caveolin-1 epithelial immunostaining patterns to stratify human breast cancer patients and predict the Caveolin-1 (P132L) mutation. Cell Cycle 8: 1396-1401, 2009. 